\title{
Genetic analysis of patients with Fuchs endothelial corneal dystrophy in India
}

\author{
Boomiraj Hemadevi ${ }^{1}$, Muthiah Srinivasan², Jambulingam Arunkumar², Namperumalsamy V Prajna², \\ Periasamy Sundaresan ${ }^{1 *}$
}

\begin{abstract}
Background: Mutations in COL8A2 gene which encodes the collagen alpha-2 (VIII) chain have been identified in both familial and sporadic cases of Fuchs endothelial corneal dystrophy (FECD). Heterozygous mutations in the SLC4A11 gene are also known to cause late-onset FECD. Therefore we screened for COL8A2, SLC4A11 gene variants in Indian FECD patients.
\end{abstract}

Methods: Eighty patients with clinically diagnosed FECD and 100 age matched normal individuals were recruited. Genomic DNA was isolated from peripheral blood leukocytes. Mutations in COL8A2, SLC4A11 coding regions were screened using bi-directional sequencing. Fischer's exact test or Pearson's chi squared test were used to predict the statistical association of genotypes with the phenotype.

Results: Screening of COL8A2 gene revealed 2 novel c.1610G>A, C.1643A>G and 3 reported variations C.112G>A, c.464G >A and c.1485G>A. In SLC4A11 gene, novel c.1659C>T, c.1974C>T and reported c.405G>A, C.481A>C and c.639G $>$ A variants were identified. However all the variations in both the genes were also present in unaffected controls.

Conclusions: This is the first study analysing COL8A2 gene in Indian patients with FECD. No pathogenic mutations were identified in COL8A2. Merely silent changes, which showed statistically insignificant association with FECD, were identified in the screening of SLC4A11 gene. These results suggest that COL8A2, SLC4A11 genes may not be responsible for FECD in patients examined in this study.

\section{Background}

The corneal endothelial dystrophies comprising Fuchs endothelial corneal dystrophy (FECD; MIM\#s 136800 and 610158), posterior polymorphous corneal dystrophy (PPCD; MIM\#s 122000, 609140 and 609141) and congenital hereditary endothelial dystrophy (CHED; MIM121700 and 217700) are thought to represent defects of neural crest terminal differentiation [1]. FECD is a degenerative, bilateral, often asymmetric and slowly progressive disorder [2]. It is characterized by a pleomorphic, attenuated, dysfunctional and degenerated corneal endothelium and the progressive formation of microscopic, refractile, posterior excrescences in the Descemet membrane (a collagen rich basal lamina) secreted by corneal endothelium, clinically known as

\footnotetext{
* Correspondence: sundar@aravind.org

'Department of Genetics, Dr G Venkataswamy Eye Research Institute

(Aravind Medical Research Foundation), \#1 Anna nagar, Madurai, Tamilnadu, India
}

\section{Biomed Central}

corneal guttae [3]. Due to endothelial dysfunction and loss of cells with FECD progression leads to corneal decompensation and impaired vision [4].

FECD may show familial clustering but it is usually a sporadic condition $[5,6]$. It occurs predominantly in females compared to the males [2,7]. Corneal grafting is the only means of restoring vision in advanced cases, however there is always the risk for allograft rejection and requires lifelong follow up.

The genotypic approach will provide better understanding, identification of the underlying genetic defects and in future enhance the possibility of medical intervention using conventional pharmacological approaches or gene therapy. Family based studies have mapped lateonset FECD susceptibility loci to 13ptel-13q12.13 [8] and 18q21.2-q21.32 [9]. Genome wide linkage analysis of 22 families with FECD identified potential linkage regions on chromosomes $1,7,15,17$, and $X$ [10]. Recently FECD is linked to a novel locus on 
5q33.1-q35.2 [11]. Mutations in the COL8A2 gene located on $1 \mathrm{p} 34.3$ have been described in patients with FECD [12-16]. This gene encodes for the collagen alpha- 2 (VIII) chain, a major component of Descemet membrane. This protein is found in the posterior banded layer (PBL) of patients with FECD $[17,18]$.

Heterozygous mutations in the SLC4A11 gene are also known to be associated with the late-onset FECD [19]. The SLC4A11 gene, which codes for sodium bicarbonate transporter-like protein 11 have been previously associated with autosomal recessive congenital hereditary endothelial dystrophy (CHED2) that also arises by the primary defect in the corneal endothelium [20].

Susceptibility of genes to mutations can vary in different ethnicities and also in view of the limited information on the genetics of FECD from India, we undertook this study. We screened for mutation in the COL8A2 and $S L C 4 A 11$ genes to determine whether these genes are responsible for causing FECD in Indian population. We report for the first time, the results of mutation analysis of the COL8A2 gene in 80 unrelated patients with early onset \& late onset FECD. A study by Vithana et al., screened 25 Indian FECD patients for SLC4A11 mutations [19], this is the first report of analysing SLC4A11 gene in a larger series of Indian patients having FECD.

\section{Methods}

\section{Patients}

All the patients and normal controls screened were recruited from Aravind Eye Hospital (A tertiary eye care centre), Madurai, Tamilnadu, India. Eighty patients studied were sporadic cases of Indian ancestry. One hundred control individuals without any eye disease were enlisted. The study protocol had the approval of Institutional Review Board of Aravind Eye Hospital. Informed consent was obtained from each individual and all studies were performed according to the tenets of the Declaration of Helsinki. All patients underwent a complete ophthalmic evaluation including a detailed medical and family history. The presence of guttae was identified using the slit lamp and confirmed by specular microscopy. Histopathological examination of corneas collected from the patients who underwent penetrating keratoplasty (PKP) was also done.

\section{Mutation analysis}

DNA was isolated from peripheral blood lymphocytes using the protocol described by Miller et al., (1988) [21]. Polymerase chain reaction (PCR) was used to amplify the 2 exons of COL8A2 (NM_005202) using 16 sets of oligonucleotide primer pairs and PCR conditions were followed as previously described in the literature [12]. For mutational analysis of SLC4A11 (NM_032034) gene, all the coding exons of $S L C 4 A 11$ and their flanking splice junctions were amplified by means of PCR using the primers reported elsewhere [20]. The PCR products were purified using a gel extraction kit (Amersham Biosciences, Piscataway, NJ), and bi-directional sequencing was performed using an ABI 3130 sequencer (Applied Biosystems, Foster City, CA).

\section{Statistical analysis}

Data was analysed using Stata 8 (Stata, college station, TX). Statistical differences in allele and genotype frequencies between the case and the control groups were determined using Pearson's chi-squared test or by Fischer's exact test respectively.

\section{Prediction of splice site alteration}

To identify whether the variants found are causing any splice site alteration, a program for recognizing the splice sites was used http://www.fruitfly.org/seq_tools/ splice.html.

\section{Results}

Eighty unrelated patients with a diagnosis of either early or late-onset FECD were enrolled in the study. All of them were sporadic cases and no family history of disease was observed. Among the 80 patients, 27 were men and 53 were women. Age of onset of symptoms was between 17 to 76 years. The probands' onset of symptoms within 40 years of age was considered as early onset and above 40 years as late onset. Fifteen cases came under the early onset category in which 5 were males and 10 were females. Their age ranged from 26 to 40 years with an average of 33.6 years (Standard Deviation (SD) 5.1). The age of 65 late onset cases ranged from 42 to 76 years with an average range of 55 years (SD 8.3) including 20 males and 45 females. The 100 unrelated controls age range was 25 to 70 years with an average of 50 years (SD 12.42). Among the 80 FECD patients 37 patients underwent PKP (bilateral- 11, unilateral-26), the age at surgery was between 36 to 77 years and all the cases were confirmed to have FECD by histopathological examination. Epithelial, stromal edema and thickened Descemet membrane was seen in all the buttons including the presence of guttae in longstanding cases.

Screening of the COL8A2 gene in the affected patients did not reveal any of the previously identified pathogenic mutations associated with FECD $[12,13,15]$, and [16]. The reported c.464G>A (p.Arg155Gln) [12,16] variant, novel variants c.1610G $>$ A (p.Asp537Asn) and c.1643A $>$ G (p.Asn548Ser) (Figure 1a, b) were found both in controls and patients with statistically insignificant association with the disease. Reported silent variants c.112G $>$ A (p. =), c.1485G $>$ A (p. $=)$ [12] were also 


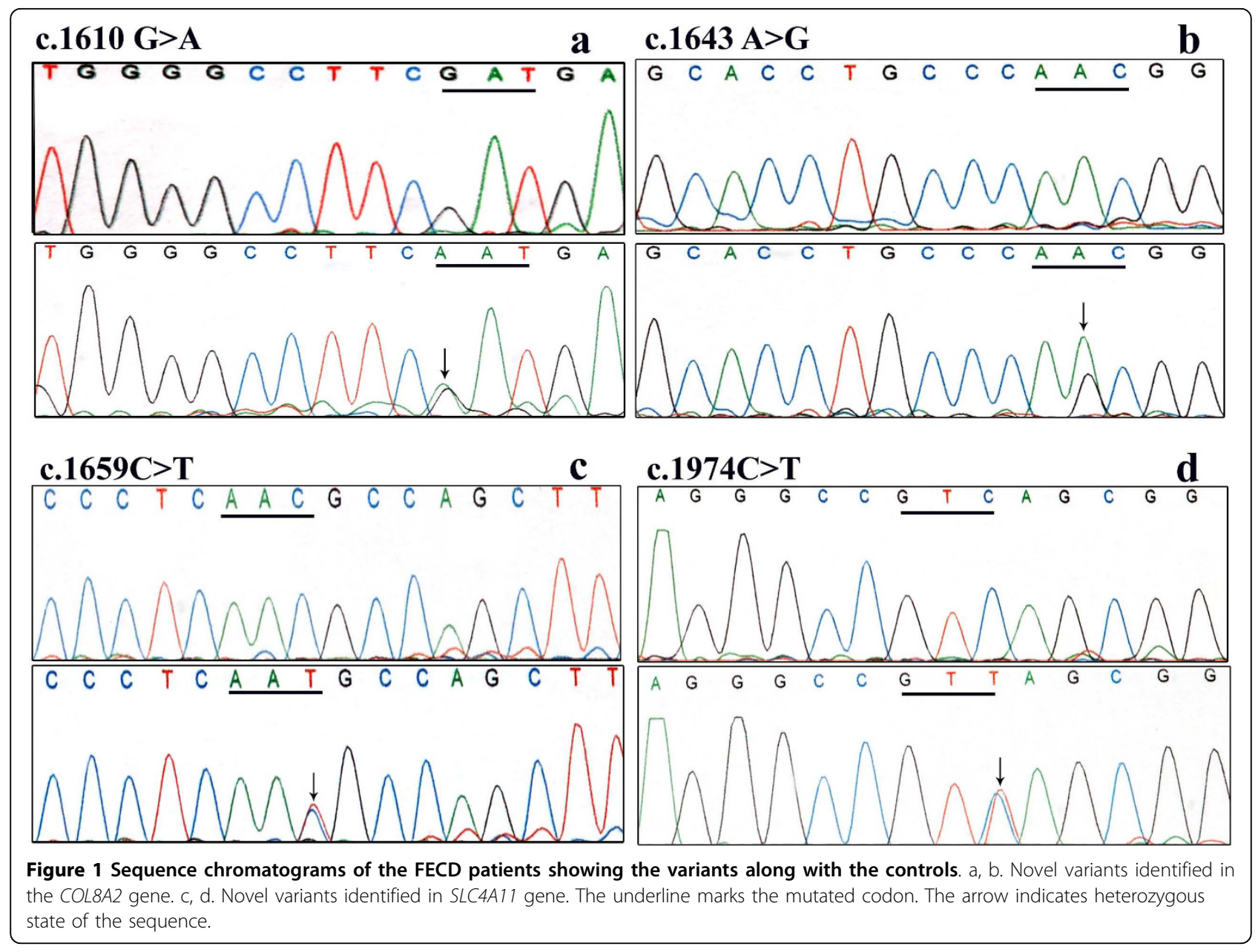

identified. The $\mathrm{p}$ values of these alleles showed significant association with the disease however the odds ratio (OR) was significantly lesser on comparing the disease with controls (Table 1).

SLC4A11 gene screening did not identify any pathogenic mutation. However 2 novel variants c.1659C $>\mathrm{T}$ (p. $=$ ), c. 1974C $>$ T (p. =) (Figure 1c, d) and 3 reported variants c.405G $>$ A (p. =), c.481A $>$ C (p. =), c.639G $>$ A (p. =) [19] were identified. None of the variants were found to have any statistically significant association with the disease (Table 1). Moreover variants identified in COL8A2 and SLC4A11 did not seem to alter any splice site.

\section{Discussion}

The exact cause of FECD is still unknown. To understand the pathogenesis, we screened for COL8A2 and SLC4A11 gene variants in our study. Previous studies in other ethnic groups identified pathogenic mutations in COL8A2 in association with FECD [12-16]. Biswas et al., [12] reported that p.Gln455Lys was detected in 3 early onset FECD families originating from Northern England and Australia. Also in their study, missense mutations p.
Arg155Gln, p.Arg304Gln and p.Arg434His were identified in the common, late onset form of FECD. Similar to this report the heterozygous p.Gln455Lys mutation was also identified in Korean patients with FECD [16]. Gottsch et al., [13] reported the segregation of COL8A2 p.Leu450Trp with the disease phenotype in American familial FECD with early onset subtype. A study by Liskova et al., also observed the same mutation in a British family with early-onset FECD [15].

At birth, the normal endothelial cells start producing the posterior non-banded layer and continue to add material throughout life. In FECD and CHED2, Descemet membrane may appear thickened as the posterior layer is attenuated or absent and is replaced by an abnormal banded layer (varying from 14 to $20 \mu \mathrm{m}$, unlike the normal thickness $12 \mu \mathrm{m}$ ) due to endothelial dysfunction. This common clinical feature implies that SLC4A11 gene, the causative gene for CHED2 may play a role in FECD, even though the onset and symptoms of CHED2 and FECD are completely dissimilar. This is supported by the identification of heterozygous missense mutations in the SLC4A11 gene in Chinese and Indian FECD patients [19]. 
Table 1 Allele and genotype frequencies of COL8A2 and SLC4A11 variants

\begin{tabular}{|c|c|c|c|c|c|c|c|c|}
\hline \multirow[t]{2}{*}{ Gene } & \multirow[t]{2}{*}{ Variation } & & & \multicolumn{2}{|c|}{ FECD } & \multicolumn{2}{|c|}{ Normal } & \multirow[t]{2}{*}{ P-value } \\
\hline & & & & $(n=80)$ & $\%$ & $(n=100)$ & $\%$ & \\
\hline \multirow[t]{25}{*}{ COL8A2 } & $c .112 \mathrm{G}>\mathrm{A}(\mathrm{p} .=)$ & Genotype & GG & 67 & 83.8 & 93 & 93 & 0.104 \\
\hline & & & GA & 9 & 11.3 & 6 & 6 & \\
\hline & & & $\mathrm{AA}$ & 4 & 5 & 1 & 1 & \\
\hline & & Allele & G & 143 & 0.894 & 192 & 0.96 & 0.014 \\
\hline & & & $\underline{A}$ & 17 & 0.106 & 8 & 0.04 & 0.014 \\
\hline & c.464G>A (Arg155Gln) & Genotype & GG & 79 & 98.8 & 93 & 93 & NS \\
\hline & & & GA & 0 & 0.0 & 5 & 5 & \\
\hline & & & AA & 1 & 1.25 & 2 & 2 & \\
\hline & & Allele & G & 158 & 0.987 & 191 & 0.955 & NS \\
\hline & & & A & 2 & 0.012 & 9 & 0.045 & \\
\hline & $c .1485 G>A(p .=)$ & Genotype & GG & 62 & 77.5 & 91 & 91 & 0.028 \\
\hline & & & GA & 13 & 16.3 & 8 & 8 & \\
\hline & & & $\mathrm{AA}$ & 5 & 6.3 & 1 & 1 & \\
\hline & & Allele & G & 137 & 0.856 & 190 & 0.95 & 0.002 \\
\hline & & & A & 23 & 0.144 & 10 & 0.05 & 0.002 \\
\hline & c.1610G >A (Asp537Asn)* & Genotype & GG & 78 & 97.5 & 95 & 95 & NS \\
\hline & & & GA & 2 & 2.5 & 5 & 5 & \\
\hline & & & $\mathrm{AA}$ & 0 & 0.0 & 0 & 0.0 & \\
\hline & & Allele & G & 158 & 0.987 & 195 & 0.975 & NS \\
\hline & & & A & 2 & 0.012 & 5 & 0.025 & \\
\hline & c.1643A>G (Asn548Ser)* & Genotype & AA & 75 & 93.8 & 93 & 93 & NS \\
\hline & & & $A G$ & 5 & 6.3 & 7 & 7 & \\
\hline & & & GG & 0 & 0.0 & 0 & 0.0 & \\
\hline & & Allele & A & 155 & 0.969 & 193 & 0.965 & NS \\
\hline & & & G & 5 & 0.131 & 7 & 0.035 & \\
\hline \multirow[t]{23}{*}{ SLC4A11 } & c.405G $>$ A (p. $=)$ & Genotype & GG & 78 & 97.5 & 94 & 94 & NS \\
\hline & & & GA & 2 & 25 & 6 & 6 & \\
\hline & & & AA & 0 & 0.0 & 0 & 0.0 & \\
\hline & & Allele & G & 158 & 0.98 & 194 & 0.97 & NS \\
\hline & & & A & 2 & 0.012 & 6 & 0.015 & \\
\hline & $c .481 \mathrm{~A}>C(p .=)$ & Genotype & $\mathrm{AA}$ & 76 & 95 & 93 & 93 & NS \\
\hline & & & $A C$ & 4 & 5 & 7 & 7 & \\
\hline & & & $\mathrm{CC}$ & 0 & 0.0 & 0 & 0.0 & \\
\hline & & Allele & A & 156 & 0.975 & 193 & 0.96 & NS \\
\hline & & & C & 4 & 0.025 & 7 & 0.035 & \\
\hline & c.639G>A (p. =) & Genotype & GG & 79 & 98.75 & 95 & 95 & NS \\
\hline & & & GA & 1 & 1.25 & 5 & 5 & \\
\hline & & & $\mathrm{AA}$ & 0 & 0.0 & 0 & 0.0 & \\
\hline & & Allele & G & 159 & 0.99 & 195 & 0.97 & NS \\
\hline & & & A & 1 & 0.006 & 5 & 0.025 & \\
\hline & c. $1659 C>T(p .=)^{*}$ & Genotype & $\mathrm{CC}$ & 72 & 90 & 95 & 95 & NS \\
\hline & & & $C T$ & 8 & 10 & 5 & 5 & \\
\hline & & & $\pi$ & 0 & 0.0 & 0 & 0.0 & \\
\hline & & Allele & C & 152 & 0.95 & 195 & 0.97 & NS \\
\hline & & & $\mathrm{T}$ & 8 & 0.05 & 5 & 0.025 & \\
\hline & c.1974C>T (p. $=)^{*}$ & Genotype & $\mathrm{CC}$ & 76 & 95 & 91 & 91 & NS \\
\hline & & & $\mathrm{CT}$ & 4 & 5 & 9 & 9 & \\
\hline & & & $\pi$ & 0 & 0.0 & 0 & 0 & \\
\hline
\end{tabular}


Table 1: Allele and genotype frequencies of COL8A2 and SLC4A11 variants (Continued)

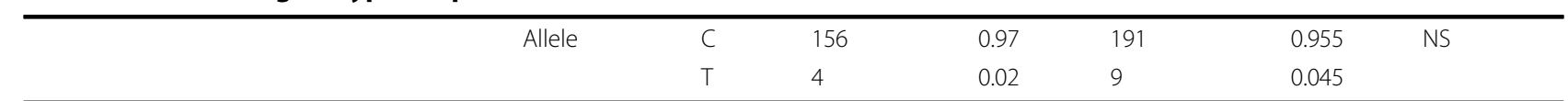

The numbering is based on the complementary DNA sequence, with +1 corresponding to the A of the ATG translation initiation codon. All the variants identified both in COL8A2 and SLC4A11 were shown in this table. Asterisk $\left(^{*}\right)$ indicates novel variants identified in this study. NS means Not Significant. P value is considered to be statistically significant if $\mathrm{P}<0.05$.

In the present study we did not identify any pathogenic mutations in COL8A2 in association with FECD. Even though association of c.112G>A (p. =) and c.1485G $>$ A (p. =) was identified with FECD patients, these mutations may not be considered as pathogenic because they do not produce any change in the encoded amino acid and also do not alter the splice site. Similarly a study by Afshari et al., [10] did not identify p. Leu450Trp and p.Gln455Lys variants in their study of screening 92 FECD patients. Kobayashi et al., [22] and Mok et al., [16] observed p.Arg155Gln and p.Thr502Met variations in the COL8A2 gene but there were no statistically significant differences in the frequencies of these 2 variations between the affected individuals and control subjects. In other 4 independent studies no mutations were identified in COL8A2 in association with both early and late-onset FECD [23-26].

In SLC4A11 screening, we identified 2 novel and 3 reported silent variants which had no significant association with FECD and did not identify any pathogenic variants. By the screening of 25 Indian FECD cases Vithana et al., identified a presumed pathogenic variant c.1195G >A (p.Glu399Lys) in SLC4A11 in a single sporadic case. Though they found association of SLC4A11 with FECD, the mutations contribute to only $5 \%$ of the genetic burden of the disease [19].

\section{Conclusions}

This is the first report analysing the COL8A2 gene in association with Indian FECD patients and we additionally studied the $S L C 4 A 11$ gene in large number of Indian cohort. In the patients screened, we did not identify any pathogenic variants in both the genes making it unlikely that single nucleotide polymorphisms or mutations in them cause FECD. The possibility of pathogenic changes being within the promoter, intronic or untranslated non coding regions of these genes playing a role in the pathogenesis of FECD has not been excluded in this study.

Together with information from previous investigations, our study suggests that locus heterogeneity exist for FECD, wherein mutations of several genes on different chromosomes may produce a common disease phenotype. In addition to the genomic approach, proteonomic approach may also shed light on the disease pathogenesis.

\section{Acknowledgements}

The authors are grateful to all the members for their participation in this study; we thank VR. Muthukkaruppan, Director of Research, Aravind Medical Research Foundation, for providing many helpful discussions; we are thankful to Dr. R. Shanthi for addressing the pathological findings; we thank Ms. Prasanthi Namburi for her assistance in sequencing; we thank Dr. Ramyadevi, S. Ananthi and Dr. Gowri priya for the critical reading of the manuscript; we also thank A. Gomathi, D. Muthuselvi and P. Pappathi for providing technical assistance; The study was supported by Department of Science and Technology, India and TIFAC-CORE in diabetic retinopathy.

\section{Author details}

'Department of Genetics, Dr G Venkataswamy Eye Research Institute (Aravind Medical Research Foundation), \#1 Anna nagar, Madurai, Tamilnadu, India. ${ }^{2}$ Cornea Services, Aravind Eye Hospital, Madurai, Tamilnadu, India.

\section{Authors' contributions}

$\mathrm{BH}$ involved in acquisition of data, analysis and interpretation of data, statistical analysis and drafting of the manuscript. MS examined and recruited the cases, involved in planning the study and revising the manuscript. JAK examined and recruited the cases, involved in drafting of the manuscript and revising the manuscript. NVP examined and recruited the cases, involved in planning the study and revising the manuscript. PS designed the study and critically reviewed and modified the manuscript. All authors have read the final version of the manuscript and approved it for publication.

\section{Competing interests}

The authors declare that they have no competing interests.

\section{Received: 29 September 2009}

Accepted: 10 February 2010 Published: 10 February 2010

\section{References}

1. Bahn CF, Falls HF, Varley GA, Meyer RF, Edelhauser HF, Bourne WM: Classification of corneal endothelial disorders based on neural crest origin. Ophthalmology 1984, 91(6):558-63.

2. Fuchs E: Dystrophia epithelialis corneae. Albrecht Van Graefes Arc Klin Exp Ophthalmol 1910, 76:478-508

3. Adamis AP, Filatov V, Tripathi BJ, Tripathi RC: Fuchs' endothelial dystrophy of the cornea. Surv Ophthalmol 1993, 38(2):149-68.

4. Waring GO, Bourne WM, Edelhauser HF, Kenyon KR: The corneal endothelium. Normal and pathologic structure and function. Ophthalmology 1982, 89(6):531-90.

5. Cross HE, Maumenee AE, Cantolino SJ: Inheritance of Fuchs' endothelial dystrophy. Arch Ophthal 1971, 85:268-272.

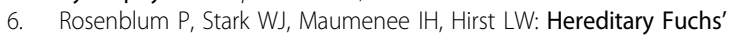
dystrophy. Am J Ophthal 1980, 90:455-462.

7. Krachmer JH, Purcell JJ Jr, Young CW, Bucher KD: Corneal endothelial dystrophy. A study of 64 families. Arch Ophthalmol 1978, 96(11):2036-9.

8. Sundin OH, Jun AS, Broman KW, Liu SH, Sheehan SE, Vito EC, Stark WJ, Gottsch JD: Linkage of late-onset Fuchs corneal dystrophy to a novel locus at 13pTel-13q12.13. Invest Ophthalmol Vis Sci 2006, 47(1):140-5.

9. Sundin $\mathrm{OH}$, Broman KW, Chang HH, Vito EC, Stark WJ, Gottsch JD: A common locus for late-onset Fuchs corneal dystrophy maps to 18q21.221.32. Invest Ophthalmol Vis Sci 2006, 47(9):3919-26.

10. Afshari NA, Li YJ, Pericak-Vance MA, Gregory S, Klintworth GK: Genomewide linkage scan in Fuchs endothelial corneal dystrophy. Invest Ophthalmol Vis Sci 2009, 50(3):1093-7.

11. Riazuddin SA, Eghrari AO, Al-Saif A, Davey L, Meadows DN, Katsanis N, Gottsch JD: Linkage of a mild late-onset phenotype of Fuchs corneal 
dystrophy to a novel locus at 5q33.1-q35.2. Invest Ophthalmol Vis Sci 2009, 50(12):5667-71.

12. Biswas S, Munier FL, Yardley J, Hart-Holden N, Perveen R, Cousin P, Sutphin JE, Noble B, Batterbury M, Kielty C, Hackett A, Bonshek R, Ridgway A, McLeod D, Sheffield VC, Stone EM, Schorderet DF, Black GC: Missense mutations in COL8A2, the gene encoding the alpha-2 chain of type VIII collagen, cause two forms of corneal endothelial dystrophy. Hum Molec Genet 2001, 10:2415-2423.

13. Gottsch JD, Sundin OH, Liu SH, Jun AS, Broman KW, Stark WJ, Vito EC Narang AK, Thompson JM, Magovern M: Inheritance of a novel COL8A2 mutation defines a distinct early-onset subtype of Fuchs corneal dystrophy. Invest Ophthalmol Vis Sci 2005, 46(6):1934-9.

14. Zhang C, Bell WR, Sundin OH, De La Cruz Z, Stark WJ, Green WR, Gottsch JD: Immunohistochemistry and electron microscopy of earlyonset fuchs corneal dystrophy in three cases with the same L450W COL8A2 mutation. Trans Am Ophthalmol Soc 2006, 104:85-97.

15. Liskova P, Prescott Q, Bhattacharya SS, Tuft SJ: British family with early onset Fuchs endothelial corneal dystrophy associated with p.L450W mutation in the COL8A2 gene. Br J Ophthalmol 2007, 91(12):1717-8.

16. Mok JW, Kim HS, Joo CK: Q455V mutation in COL8A2 is associated with Fuchs corneal dystrophy in Korean patients. Eye 2009, 23:895-903.

17. Marshall $G E$, Konstas $A G$, Lee WR: Immunogold fine structural localization of extracellular matrix components in aged human cornea. I. Types I- IV collagen and laminin. Graefes Arch Clin Exp Ophthalmol 1991, 229(2):157-63.

18. Levy SG, Moss J, Sawada H, Dopping-Hepenstal PJ, McCartney AC: The composition of wide-spaced collagen in normal and diseased Descemet's membrane. Curr Eye Res 1996, 15(1):45-52.

19. Vithana EN, Morgan PE, Ramprasad V, Tan DT, Yong VH, Venkataraman D, Venkatraman A, Yam GH, Nagasamy S, Law RW, Rajagopal R, Pang CP, Kumaramanickevel G, Casey JR, Aung T: SLC4A11 mutations in Fuchs endothelial corneal dystrophy. Hum Mol Genet 2008, 17(5):656-66.

20. Vithana EN, Morgan P, Sundaresan P, Ebenezer ND, Tan DT, Mohamed MD, Anand S, Khine KO, Venkataraman D, Yong VH, Salto-Tellez M,

Venkatraman A, Guo K, Hemadevi B, Srinivasan M, Prajna V, Khine M, Casey JR, Inglehearn CF, Aung T: Mutations in sodium-borate cotransporter SLC4A11 cause recessive congenital hereditaryendothelial dystrophy (CHED2). Nat Genet 2006, 38(7):755-7.

21. Miller SA, Dykes DD, Polesky HF: A simple salting out procedure for extracting DNA from human nucleated cells. Nucleic Acids Res 1988, 16:1215.

22. Kobayashi A, Fujiki K, Murakami A, Kato T, Chen LZ, Onoe H, Nakayasu K, Sakurai M, Takahashi M, Sugiyama K, Kanai A: Analysis of COL8A2 gene mutation in Japanese patients with Fuchs endothelial dystrophy and posterior polymorphous dystrophy. Jpn J Ophthalmol 2004, 48(3):195-8.

23. Aldave AJ, Rayner SA, Salem AK, Yoo GL, Kim BT, Saeedian M, Sonmez B, Yellore VS: No pathogenic mutations identified in the COL8A1 and COL8A2 genes in familial Fuchs corneal dystrophy. Invest Ophthalmol Vis Sci 2006, 47(9):3787-90.

24. Urquhart JE, Biswas S, Black GC, Munier FL, Sutphin J: Exclusion of COL8A1, the gene encoding the alpha2(VIII) chain of type VIII collagen, as a candidate for Fuchs endothelial dystrophy and posterior Polymorphous corneal dystrophy. Br J Ophthalmol 2006, 90(11):1430-1.

25. Mehta JS, Vithana EN, Tan DT, Yong VH, Yam GH, Law RW, Chong WG, Pang CP, Aung T: Analysis of the posterior polymorphous corneal dystrophy 3 gene, TCF8, in late-onset Fuchs endothelial corneal dystrophy. Invest Ophthalmol Vis Sci 2008, 49(1):184-8.

26. Boutboul S, Vetu C, Abitbol M, Menasche M, Borderie V, Laroche L: No Pathogenic Mutations Identified in the COL8A2 Gene in French Families of Fuchs Corneal Dystrophy and CHED. Invest Ophthalmol Vis Sci 2009, 50, E-Abstract 2304.

\section{Pre-publication history}

The pre-publication history for this paper can be accessed here:http://www. biomedcentral.com/1471-2415/10/3/prepub

doi:10.1186/1471-2415-10-3

Cite this article as: Hemadevi et al: Genetic analysis of patients with Fuchs endothelial corneal dystrophy in India. BMC Ophthalmology 2010 10:3.

\section{Submit your next manuscript to BioMed Central and take full advantage of:}

- Convenient online submission

- Thorough peer review

- No space constraints or color figure charges

- Immediate publication on acceptance

- Inclusion in PubMed, CAS, Scopus and Google Scholar

- Research which is freely available for redistribution 